\title{
Hygroscopic behavior of atmospheric aerosols containing nitrate salts and water-soluble organic acids
}

\author{
Bo Jing ${ }^{1}$, Zhen Wang ${ }^{1,2}$, Fang Tan ${ }^{1,2}$, Yucong Guo ${ }^{1}$, Shengrui Tong ${ }^{1}$, Weigang Wang ${ }^{1}$, Yunhong Zhang ${ }^{3}$, and \\ Maofa Ge $\mathbf{G}^{1,2,4}$ \\ ${ }^{1}$ State Key Laboratory for Structural Chemistry of Unstable and Stable Species, CAS Research/Education Center for \\ Excellence in Molecular Sciences, Institute of Chemistry, Chinese Academy of Sciences, Beijing 100190, P. R. China \\ ${ }^{2}$ University of Chinese Academy of Sciences, Beijing 100049, P. R. China \\ ${ }^{3}$ The Institute of Chemical Physics, School of Chemistry and Chemical Engineering, Beijing Institute of Technology, \\ Beijing 100081, P. R. China \\ ${ }^{4}$ Center for Excellence in Regional Atmospheric Environment, Institute of Urban Environment, \\ Chinese Academy of Sciences, Xiamen 361021, P. R. China
}

Correspondence: Maofa Ge (gemaofa@iccas.ac.cn)

Received: 27 October 2017 - Discussion started: 22 November 2017

Revised: 26 March 2018 - Accepted: 27 March 2018 - Published: 16 April 2018

\begin{abstract}
While nitrate salts have critical impacts on environmental effects of atmospheric aerosols, the effects of coexisting species on hygroscopicity of nitrate salts remain uncertain. The hygroscopic behaviors of nitrate salt aerosols $\left(\mathrm{NH}_{4} \mathrm{NO}_{3}, \mathrm{NaNO}_{3}, \mathrm{Ca}\left(\mathrm{NO}_{3}\right)_{2}\right)$ and their internal mixtures with water-soluble organic acids were determined using a hygroscopicity tandem differential mobility analyzer (HTDMA). The nitrate salt / organic acid mixed aerosols exhibit varying phase behavior and hygroscopic growth depending upon the type of components in the particles. Whereas pure nitrate salt particles show continuous water uptake with increasing relative humidity $(\mathrm{RH})$, the deliquescence transition is still observed for ammonium nitrate particles internally mixed with organic acids such as oxalic acid and succinic acid with a high deliquescence point. The hygroscopicity of submicron aerosols containing sodium nitrate and an organic acid is also characterized by continuous growth, indicating that sodium nitrate tends to exist in a liquid-like state under dry conditions. It is observed that in contrast to the pure components, the water uptake is hindered at low and moderate RH for calcium nitrate particles containing malonic acid or phthalic acid, suggesting the potential effects of mass transfer limitation in highly viscous mixed systems. Our findings improve fundamental understanding of the phase behavior and water uptake of nitrate-salt-containing aerosols in the atmospheric environment.
\end{abstract}

\section{Introduction}

Atmospheric aerosols exert significant impacts on the earth's radiation balance by absorbing or scattering solar radiation and modifying the properties of clouds, which result in large uncertainty in climate forcing (Haywood and Boucher, 2000; Carslaw et al., 2013). The hygroscopic particles can provide a liquid water medium for multiphase and aqueous-phase chemical processes that influence chemical constituents in the condensed and gas phase (G. Wang et al., 2016; Cheng et al., 2016; Hodas et al., 2014; Faust et al., 2017; Tan et al., 2016; Li et al., 2017). It has been established that aerosol liquid water could promote the formation of secondary organic aerosol (SOA) through the partitioning of gas-phase watersoluble organic compounds to the condensed phase and subsequent aqueous-phase processing (Hodas et al., 2014; Faust et al., 2017). The hygroscopic behavior and water content of aerosols in the atmosphere are highly dependent upon the chemical composition, mixing state and ambient relative humidity (RH) (Martin, 2000; Choi and Chan, 2002; Krieger et al., 2012). The atmospheric process or chemical aging plays an important role in the chemical composition and mixing state of aerosol particles and thus impacts aerosol hygroscopicity (Boreddy et al., 2015, 2014b). The atmospheric particulate matter from multiple biogenic and anthropogenic sources is commonly composed of complex inorganic and organic compounds with various physicochemical properties. 
The nitrate salts are ubiquitous and account for a large fraction of inorganic constituents within the atmospheric particulate matter in urban/polluted environments, especially in winter (Huang et al., 2014; Zhang et al., 2015). For example, chemical analyses have shown that nitrate typically constitutes a fraction $(7-14 \%)$ of the total particulate matter during high pollution events at the urban sites of China (Huang et al., 2014). The nitrate content can even dominate $22-24 \%$ of mass fractions of particulate matter in some urban areas such as Beijing and Los Angeles (Zhang et al., 2015). The majority of nitrate salts in ambient particles exist as $\mathrm{NH}_{4} \mathrm{NO}_{3}$, $\mathrm{NaNO}_{3}$ and $\mathrm{Ca}\left(\mathrm{NO}_{3}\right)_{2}$ depending on the environmental conditions and chemical formation mechanisms. The formation of nitrate salts is typically attributed to atmospheric reactions of ammonia, sea salt and mineral dust with nitric acid or nitrogen oxides such as $\mathrm{NO}_{2}, \mathrm{NO}_{3}$ and $\mathrm{N}_{2} \mathrm{O}_{5}$ (Zhang et al., 2015). In urban areas, due to the considerable influence of anthropogenic sources, the major chemical form of nitrate salts in fine particulate matter is ammonium nitrate generated via the heterogeneous reaction between $\mathrm{HNO}_{3}$ and $\mathrm{NH}_{3}$ in the aerosol phase. Field measurements and laboratory studies have indicated that the mineral dust $\left(\mathrm{CaCO}_{3}\right)$ and sea salt $(\mathrm{NaCl})$ emitted from natural sources could undergo atmospheric aging through the heterogeneous reactions with nitric acid or nitrogen oxides, resulting in the formation of $\mathrm{Ca}\left(\mathrm{NO}_{3}\right)_{2}$ and $\mathrm{NaNO}_{3}$ (Zhang et al., 2015). The inorganic salts in the particle phase are generally internally mixed with organic compounds that contribute a large fraction of fine particulate matter. Field measurements have confirmed that the organic fraction of the aerosols contains large amounts of water-soluble organic compounds (WSOCs) (Saxena and Hildemann, 1996; Gysel et al., 2004; Decesari et al., 2005), which affect the hygroscopicity of inorganic components (Boreddy et al., 2014a; Boreddy and Kawamura, 2016). It has been found that water-soluble organic acids such as dicarboxylic acids are representative and important constituents of the WSOCs (Kawamura and Ikushima, 1993; Kawamura et al., 1996; Decesari et al., 2006; Kawamura and Bikkina, 2016). Among the water-soluble organic acids, oxalic acid, malonic acid, succinic acid and phthalic acid are typically identified as the most abundant dicarboxylic acids in atmospheric particles (Kawamura and Bikkina, 2016).

The phase state of aerosol particles is an important factor in determining the particle's physicochemical properties and climate effects (Kanakidou et al., 2005). Due to its significance, the comprehensive understanding of the particle phase in aerosols with varying components could improve the prediction ability of climate models (Kanakidou et al., 2005; Virtanen et al., 2010; Shiraiwa et al., 2017). Unlike sulfates such as ammonium sulfate with distinct phase transition behaviors, the nitrate salts including ammonium nitrate, especially in submicron particles, tend to take up water continuously from low RH without obvious phase transitions (Mikhailov et al., 2004; Gibson et al., 2006). Previous observations indicated that pure $\mathrm{NH}_{4} \mathrm{NO}_{3}$ droplets were difficult to homogeneously crystallize and thus remained in the liquidlike state even under extremely dry conditions $(<1 \% \mathrm{RH})$ while it could efflorescence with the presence of the solid core in the droplets (Lightstone et al., 2000). Soluble inorganic crystalline particles acting as the contact nuclei were found to induce crystallization of aqueous ammonium nitrate (Davis et al., 2015). It was found that the phase state of $\mathrm{NH}_{4} \mathrm{NO}_{3}$ tended to be substantially affected by coexisting species such as ammonium sulfate and succinic acid (Lightstone et al., 2000; Liu et al., 2016). The previous hygroscopic studies have focused on the hygroscopicity of ammonium sulfate and its relevant mixtures with organics such as water-soluble organic acids (Cruz and Pandis, 2000; Choi and Chan, 2002; Prenni et al., 2003; Wise et al., 2003; Badger et al., 2006; Hodas et al., 2015; Wang et al., 2017). However, the overall role of the water-soluble organic acids in hygroscopic growth and phase behavior of the nitrate salts remains uncertain. Thus, related studies are of importance for the understanding of their environmental effects.

In this work, the hygroscopic behaviors of internally mixed aerosols composed of atmospherically relevant nitrate salts and water-soluble organic acids are determined under subsaturation conditions with a hygroscopicity tandem differential mobility analyzer (HTDMA) system. The measured hygroscopic growth of relevant aerosols is compared with predictions from the Zdanovskii-Stokes-Robinson (ZSR) method based on the hygroscopicity of individual components. The significant effects of water-soluble organic acids with various hygroscopic characteristics on water uptake behaviors of nitrate salts have been confirmed, and relevant atmospheric implications are discussed.

\section{Experimental and method section}

\subsection{Reagents}

Table 1 summarizes chemical properties and manufacturers of nitrate salts (ammonium nitrate, sodium nitrate and calcium nitrate) and water-soluble organic acids (oxalic, malonic, succinic and phthalic acids) in this study. Aerosol particles were generated from a $0.1 \mathrm{wt} \%$ aqueous solution of pure component or mixtures containing nitrate salts and organic acids at a specific mass ratio. The corresponding solutions were prepared using ultrapure water (EASY Pure ${ }^{\circledR}$ II UF ultrapure water system, resistivity $\geq 18.2 \mathrm{M} \Omega \mathrm{cm}$ ).

\subsection{Hygroscopic growth measurements}

In this study, the hygroscopicity tandem differential mobility analyzer (HTDMA) system was used to measure the hygroscopic growth of aerosol particles studied. This system has been fully described in our previous studies (Jing et al., 2016, 2017; Peng et al., 2016). Briefly, the HTDMA setup consists of the aerosols' generation and drying section, humidity control apparatus and the particle size selec- 
Table 1. Chemical properties of substances investigated in this study.

\begin{tabular}{|c|c|c|c|c|c|}
\hline $\begin{array}{l}\text { Chemical } \\
\text { compounds }\end{array}$ & $\begin{array}{l}\text { Molecular } \\
\text { formula }\end{array}$ & $\begin{array}{l}\text { Molar weight } \\
\qquad\left(\mathrm{g} \mathrm{mol}^{-1}\right)\end{array}$ & $\begin{array}{r}\text { Density } \\
\left(\mathrm{g} \mathrm{cm}^{-3}\right)\end{array}$ & $\begin{array}{r}\text { Solubility } \\
\left(\mathrm{g} 100 \mathrm{~cm}^{-3} \mathrm{H}_{2} \mathrm{O}\right)^{\mathrm{a}}\end{array}$ & Manufacturer/purity \\
\hline Ammonium nitrate & $\mathrm{NH}_{4} \mathrm{NO}_{3}$ & 80.0 & 1.72 & 213 & Dtftchem, $99 \%$ \\
\hline Sodium nitrate & $\mathrm{NaNO}_{3}$ & 85.0 & 2.26 & 91.2 & Alfa Aesar, $\geq 99.0 \%$ \\
\hline Calcium nitrate & $\mathrm{Ca}\left(\mathrm{NO}_{3}\right)_{2}$ & 164.1 & 2.5 & 144 & \\
\hline Calcium nitrate tetrahydrate & $\mathrm{Ca}\left(\mathrm{NO}_{3}\right)_{2} \cdot 4 \mathrm{H}_{2} \mathrm{O}$ & 236.1 & 1.82 & 144 & Alfa Aesar, $99.0 \%$ \\
\hline Oxalic acid & $\mathrm{C}_{2} \mathrm{H}_{2} \mathrm{O}_{4}$ & 90.0 & 1.90 & 9.5 & Aldrich, $99.999 \%$ \\
\hline Oxalic acid (dihydrate) & $\mathrm{C}_{2} \mathrm{H}_{2} \mathrm{O}_{4} \cdot 2 \mathrm{H}_{2} \mathrm{O}$ & 126.1 & 1.65 & & \\
\hline Malonic acid & $\mathrm{C}_{3} \mathrm{H}_{4} \mathrm{O}_{4}$ & 104.1 & 1.62 & 76 & Sigma-Aldrich, $99 \%$ \\
\hline Succinic acid & $\mathrm{C}_{4} \mathrm{H}_{6} \mathrm{O}_{4}$ & 118.1 & 1.57 & 8.35 & Sigma-Aldrich, $\geq 99.5 \%$ \\
\hline Phthalic acid & $\mathrm{C}_{8} \mathrm{H}_{6} \mathrm{O}_{4}$ & 166.1 & 1.59 & $0.41^{\mathrm{b}}$ & Sigma-Aldrich, $\geq 99.5 \%$ \\
\hline
\end{tabular}

${ }^{\mathrm{a}}$ From CRC Handbook of Chemistry and Physics at $298 \mathrm{~K} .{ }^{\mathrm{b}}$ From Hartz et al. (2006).

tion and detection system. The polydisperse particles were generated from a constant output atomizer containing the sample solution, and then passed through a silica gel diffusion dryer combined with a Nafion gas dryer to be dried to $\mathrm{RH}<5 \%$. After being charged by a neutralizer, the dry particles were transformed into quasi-monodisperse particles with a mobility diameter of $100 \mathrm{~nm}$ by the first differential mobility analyzer (DMA1). The size-selected aerosols then entered the humidity control apparatus where they were exposed and equilibrated to a given $\mathrm{RH}$ in the range of $<5$ to $90 \%$ with a residence time of $5 \mathrm{~s}$. The size distribution of aerosols after humidification was determined by the second DMA (DMA2) and the condensation particle counter (CPC, MSP 1500). Sheath air in the DMA2 was drawn from the humidity control section to ensure no change in humidity of aerosol flow in the DMA2. The RH of sheath flow was measured at the outlet of DMA2 using a dew point hygrometer (Michell, UK) with an uncertainty of $\pm 0.8 \%$ RH and $\pm 0.1 \mathrm{~K}$. The sheath and aerosol flow rates in both DMAs were 3.0 and $0.3 \mathrm{~L} \mathrm{~min}^{-1}$, respectively. The inversion of HTDMA measurement data was based on a lognormal size distribution approximation (Stolzenburg and McMurry, 2008). All hygroscopicity measurements were conducted at ambient temperature $(295 \pm 1 \mathrm{~K})$. During the experiment process, no obvious evaporation (no obvious decrease between dry particle size selected by DMA1 and that measured by DMA2) of nitrate-salt-containing particles was observed under our measurement conditions.

The hygroscopic growth factor (GF) is calculated by $\mathrm{GF}=D_{\text {wet }} / D_{\text {dry }}$, where $D_{\text {wet }}$ is the diameter of particles measured by DMA2 at a particular RH and $D_{\text {dry }}$ is the diameter of dry particles measured by DMA 2 at $\leq 5 \% \mathrm{RH}$. Considering the curvature effect for submicron droplets, the RH was converted to water activity $a_{\mathrm{w}}$ in subsequent data analysis by the Köhler equation:

$\mathrm{RH}=a_{\mathrm{w}} \exp \left(\frac{4 M_{\mathrm{w}} \sigma_{\mathrm{sol}}}{R T \rho_{\mathrm{w}} D_{p}}\right)$.
Here, $M_{\mathrm{w}}$ is the molar mass of water, $\sigma_{\mathrm{sol}}$ is the surface tension of the droplet, $R$ is ideal gas constant, $T$ is temperature, $\rho_{\mathrm{w}}$ is the density of water and $D_{p}$ is the droplet diameter. In this study, the effects of solutes on the surface tension of the droplet were not obvious, and thus the surface tension of pure water $\left(0.072 \mathrm{~J} \mathrm{~m}^{-2}\right)$ was used in estimates by Eq. (1). During the experimental period, the hygroscopic growth of ammonium sulfate was measured regularly to validate the measurement reliability of the HTDMA. The RH measurement uncertainty was determined by measuring hydration curves of three inorganic salts such as sodium chloride $(\mathrm{NaCl})$, ammonium sulfate $\left[\left(\mathrm{NH}_{4}\right)_{2} \mathrm{SO}_{4}\right]$ and potassium chloride $(\mathrm{KCl})$. It was found that the discrepancies between measured deliquescence points and theory predictions for the three salts were within $\pm 1.5 \% \mathrm{RH}$, which was used to estimate the measurement uncertainty in RH. All measured GFs at a given $\mathrm{RH}$ are the average values of at least three repeated measurements, with the corresponding standard deviation less than 0.02 . The measured deliquescence point and GFs of ammonium sulfate agreed well with our previous studies and other reported literature values (Peng et al., 2016; Jing et al., 2017; Sjogren et al., 2007). For example, the hygroscopic growth factors of $100 \mathrm{~nm}$ ammonium sulfate particles at 80 and $90 \% \mathrm{RH}$ were determined to be 1.44 and 1.68 , respectively, consistent with the literature results $(\mathrm{GF}(80 \% \mathrm{RH})=1.46$ and $\mathrm{GF}(90 \% \mathrm{RH})=1.69$, Sjogren et al., 2007).

The morphology of suspended particles was observed using scanning electron microscopy (SEM, S-4300, Hitachi). The SEM samples were prepared by using the aerosol generation, drying and humidification section of the HTDMA system without undergoing the size selection. The particles were deposited onto the silicon wafers, which were either put at the output of the silica gel diffusion dryer with RH less than $10 \%$, or at the output of the Nafion humidification tube with $30 \% \mathrm{RH}$. The deposited particles were used for SEM measurement. 


\subsection{Model methods}

The Aerosol Inorganic-Organic Mixtures Functional groups the Activity Coefficients (AIOMFAC) model is applied to estimate the hygroscopic growth of the three nitrate salts. The AIOMFAC has been developed to describe the activities of atmospherically relevant aqueous solutions up to high ionic concentrations at room temperature (Zuend et al., 2008, 2011). The AIOMFAC predictions for nitrate salts are based on fitted water activity data. The fitted water activity data of ammonium nitrate are derived from measurements by Hamer and Wu (1972) and Robinson and Stokes (2002). The sodium nitrate data are based on measurements from Hamer and Wu (1972) and Tang and Munkelwitz (1994). The fitted water activity data of calcium nitrate are derived from measurements by Robinson and Stokes (2002).

The Zdanovskii-Stokes-Robinson (ZSR) method is used to estimate the hygroscopic growth of internally mixed particles by assuming that each component in the mixed particles takes up water independently (Malm and Kreidenweis, 1997; Stokes and Robinson, 1966). The total water uptake by mixed particles is the sum of water content associated with each pure component, which can be expressed by the following equation:

$\mathrm{GF}_{\text {mixed }}=\left(\sum_{k} \varepsilon_{k} \cdot \mathrm{GF}_{k}^{3}\right)^{1 / 3}$,

where $\mathrm{GF}_{\text {mixed }}$ and $\mathrm{GF}_{k}$ is the hygroscopic growth factor of the mixed particle and component $k$, respectively, and $\varepsilon_{k}$ is the volume fraction of component $k$ in the dry particle. The volume fraction $\varepsilon_{k}$ is obtained by

$\varepsilon_{k}=\frac{\left(w_{k} / \rho_{k}\right)}{\sum_{i}\left(w_{i} / \rho_{i}\right)}$.

Here $w_{k}$ is the mass fraction of component $k$, and $\rho_{k}$ is the density of component $k$. Although the ZSR relation does not take into account the interactions between components in the mixture, this simple method has been found to be a valuable tool to predict the water uptake of atmospherically relevant mixtures under high RH conditions (Prenni et al., 2003). In the present study, the ZSR calculations are derived from the hydration curve of nitrate salts predicted from the AIOMFAC model and the three-parameter fit curve of organic acids (seen in Fig. S1 in the Supplement).

According to $\kappa$-Köhler theory proposed by Petters and Kreidenweis (2007), a single hygroscopicity parameter $\kappa$ can be obtained based on hygroscopic growth measurements under subsaturated conditions (Carrico et al., 2008):

$\kappa=\frac{\left(\mathrm{GF}^{3}-1\right)\left(1-a_{\mathrm{w}}\right)}{a_{\mathrm{w}}}$,

where $a_{\mathrm{w}}$ is the water activity and GF is the hygroscopic growth factor. Petters and Kreidenweis (2007) found that the $\kappa$ values derived from the hygroscopic growth data at $\mathrm{RH} \sim 90 \%$ are generally consistent with that derived from the measured cloud condensation nuclei $(\mathrm{CCN})$ activity data. The GFs of pure nitrate salt particles at $90 \% \mathrm{RH}$ are converted into $\kappa$ values by using Eq. (4).

\section{Results and discussion}

\subsection{Water uptake behaviors of single components}

Table 2 summarizes hygroscopic growth factors of nitratesalt-containing particles in this study. The hygroscopic growth of single components including three nitrate salts is shown in Fig. 1. The three nitrate salts present gradual hygroscopic growth without prompt deliquescence transitions over the whole RH range studied. The smooth hygroscopic growth suggests the nitrate salt particles likely remain in a liquidlike or amorphous state at the lowest $\mathrm{RH}$, as also observed by previous studies (Lightstone et al., 2000; Gibson et al., 2006). For example, the early HTDMA studies by Mikhailov et al. (2004) and Svenningsson et al. (2006) also observed the continuous water uptake behavior of submicron ammonium nitrate particles without any prompt deliquescence transition. Although crystalline sodium nitrate has a deliquescence point at $74.5 \%$ RH (Tang and Munkelwitz, 1994), the prior studies found that micron and submicron $\mathrm{NaNO}_{3}$ particles formed from aqueous solutions exhibited continuous hygroscopic growth due to initial particles in a metastable or amorphous form, even at zero relative humidity (Gysel et al., 2002; Hoffman et al., 2004; Gibson et al., 2006). In this study, the measured growth factor for $100 \mathrm{~nm} \mathrm{NaNO}_{3}$ particles is 1.97 at $90 \% \mathrm{RH}$, in good agreement with the literature value of 1.91 (Gysel et al., 2002). For calcium nitrate, $\mathrm{Ca}\left(\mathrm{NO}_{3}\right)_{2}$ particles gradually take up water with increasing $\mathrm{RH}$, and the measured hygroscopic growth generally matches the subsequent theory prediction based on the assumption that submicron $\mathrm{Ca}\left(\mathrm{NO}_{3}\right)_{2}$ particles at low $\mathrm{RH}$ exist as amorphous hydrates (tetrahydrate, $\mathrm{Ca}\left(\mathrm{NO}_{3}\right)_{2} \cdot 4 \mathrm{H}_{2} \mathrm{O}$ ) (Gibson et al., 2006). The GF of $100 \mathrm{~nm} \mathrm{Ca}\left(\mathrm{NO}_{3}\right)_{2}$ particles is determined to be 1.56 and 1.89 at 80 and $90 \% \mathrm{RH}$, respectively, consistent with the corresponding predicted values of 1.52 and 1.82. As shown in Fig. S3, the nitrate salt particles stay in a liquid-like state at low RH less than $10 \%$. The Raman spectrum of ammonium nitrate shows no obvious absorption between 3400 and $3600 \mathrm{~cm}^{-1}$ for the water peak feature, indicating that the liquid-like particle appears to be an amorphous solid. As shown in Fig. 1, the measured GFs of the three nitrate salts over the RH range studied are in fair agreement with the predictions from the AIOMFAC model based on the dehydration process, which also suggests nitrate salt particles remain noncrystalline, even at the lowest RH. Compared to ammonium and sodium nitrates, $\mathrm{Ca}\left(\mathrm{NO}_{3}\right)_{2}$ can form amorphous hydrates under dry conditions (Gibson et al., 2006). On the basis of thermodynamic 
Table 2. Hygroscopic growth factors of nitrate-salt-containing particles in this study. The predictions for pure components and mixtures are from the AIOMFAC model and the ZSR relation, respectively. For oxalic-acid-containing mixtures, the predicted values based on measurements from Mikhailov et al. (2009) are shown in brackets.

\begin{tabular}{|c|c|c|c|c|c|c|}
\hline & \multicolumn{3}{|c|}{ GF $(80 \% \mathrm{RH})$} & \multicolumn{3}{|c|}{ GF $(90 \% \mathrm{RH})$} \\
\hline & Measured & Predicted & Literature & Measured & Predicted & Literature \\
\hline \multicolumn{7}{|l|}{ Pure component } \\
\hline $\mathrm{NH}_{4} \mathrm{NO}_{3}$ & 1.42 & 1.41 & $1.40^{\mathrm{a}}$ & 1.70 & 1.72 & $1.75^{\mathrm{a}}$ \\
\hline $\mathrm{NaNO}_{3}$ & 1.62 & 1.63 & $1.60^{\mathrm{b}}$ & 1.97 & 1.95 & $1.91^{\mathrm{b}}$ \\
\hline $\mathrm{Ca}\left(\mathrm{NO}_{3}\right)_{2}$ & 1.56 & 1.52 & $1.51^{\mathrm{c}}$ & 1.89 & 1.82 & NA \\
\hline \multicolumn{7}{|l|}{ Equal mass mixtures } \\
\hline $\mathrm{NH}_{4} \mathrm{NO}_{3} /$ oxalic acid & 1.07 & $1.23(1.33)$ & NA & 1.64 & $1.44(1.65)$ & NA \\
\hline $\mathrm{NH}_{4} \mathrm{NO}_{3} /$ malonic acid & 1.41 & 1.38 & NA & 1.91 & 1.81 & NA \\
\hline $\mathrm{NH}_{4} \mathrm{NO}_{3} /$ succinic acid & 1.26 & 1.24 & NA & 1.74 & 1.52 & NA \\
\hline $\mathrm{NH}_{4} \mathrm{NO}_{3} /$ phthalic acid & 1.27 & 1.28 & NA & 1.69 & 1.62 & NA \\
\hline $\mathrm{NaNO}_{3} /$ oxalic acid & 1.37 & $1.27(1.38)$ & NA & 1.79 & $1.53(1.75)$ & NA \\
\hline $\mathrm{NaNO}_{3} /$ malonic acid & 1.44 & 1.47 & NA & 2.02 & 1.93 & NA \\
\hline $\mathrm{NaNO}_{3} /$ succinic acid & 1.52 & 1.32 & NA & 2.09 & 1.68 & NA \\
\hline $\mathrm{NaNO}_{3} /$ phthalic acid & 1.22 & 1.37 & NA & 1.61 & 1.68 & NA \\
\hline $\mathrm{Ca}\left(\mathrm{NO}_{3}\right)_{2} /$ malonic acid & 1.32 & 1.44 & NA & 1.87 & 1.77 & NA \\
\hline $\mathrm{Ca}\left(\mathrm{NO}_{3}\right)_{2} /$ phthalic acid & 1.28 & 1.37 & NA & 1.93 & 1.65 & NA \\
\hline
\end{tabular}

${ }^{\mathrm{a}}$ Hu et al. (2011). ${ }^{\mathrm{b}}$ Gysel et al. (2002). ${ }^{\mathrm{c}}$ Gibson et al. (2006). NA: not available.

considerations, tetrahydrate $\left(\mathrm{Ca}\left(\mathrm{NO}_{3}\right)_{2} \cdot 4 \mathrm{H}_{2} \mathrm{O}\right)$ is the stable hydrate for calcium nitrate. The previous study also applied tetrahydrate data to calculate the theoretical growth factors of $\mathrm{Ca}\left(\mathrm{NO}_{3}\right)_{2}$ due to the lack of detailed amorphous hydrate data (Gibson et al., 2006). Similarly, the AIOMFAC predictions for $\mathrm{Ca}\left(\mathrm{NO}_{3}\right)_{2}$ in our study are based on the tetrahydrate data. It can be expected that the discrepancies between properties (density and molar mass) of amorphous hydrates and tetrahydrate could result in the slight deviation between AIOMFAC predictions and measurements. The $\kappa$ values of pure nitrate salt particles are derived from the GFs at $90 \%$ RH by using Eq. (4). The calculated $\kappa$ value in this study is $0.537,0.821$ and 0.658 for ammonium nitrate, sodium nitrate and calcium nitrate, respectively, in agreement with the corresponding value of 0.577 for ammonium nitrate and 0.80 for sodium nitrate in the literature (Petters and Kreidenweis, 2007).

For the organic acids studied (seen in Fig. S1 in the Supplement), oxalic acid (OA) and succinic acid (SA) present no deliquescence transition or any obvious water uptake below $90 \%$ RH, which agrees well with previous studies (Jing et al., 2016; Peng et al., 2001). The observation of no evaporation losses (no decrease between dry particle size selected by DMA1 and that measured by DMA2) for dry OA particles is consistent with other HTDMA studies, suggesting that the generated particles after the drying process exist as crystalline OA dihydrate with low vapor pressure (Prenni et al., 2001; Mikhailov et al., 2009). The GFs of aqueous OA from the dehydration curve measured by Mikhailov et al. (2009) are applied to estimate ZSR predictions when assuming that

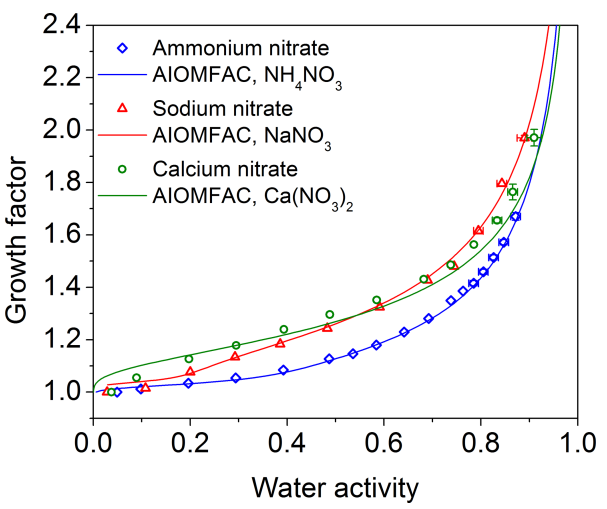

Figure 1. Hygroscopic growth factors of $100 \mathrm{~nm} \mathrm{NH}_{4} \mathrm{NO}_{3}, \mathrm{NaNO}_{3}$ and $\mathrm{Ca}\left(\mathrm{NO}_{3}\right)_{2}$ particles as a function of water activity. The corresponding AIOMFAC-predicted curve associated with measurements is also presented. The error bars representing the standard deviation of multiple measurements are generally not obvious compared to the size of the symbols.

$\mathrm{OA}$ in the mixture contributes to water uptake at high $\mathrm{RH}$. The malonic acid (MA) and phthalic acid (PA) exhibit continuous water uptake behaviors across all RH studied, consistent with the observations in other studies (Prenni et al., 2001; Brooks et al., 2004; Jing et al., 2016). The measured GF of $100 \mathrm{~nm}$ malonic acid particles at 80 and $90 \% \mathrm{RH}$ is 1.34 and 1.65 , respectively, consistent with corresponding literature values of 1.37 and 1.73 (Prenni et al., 2001). The 

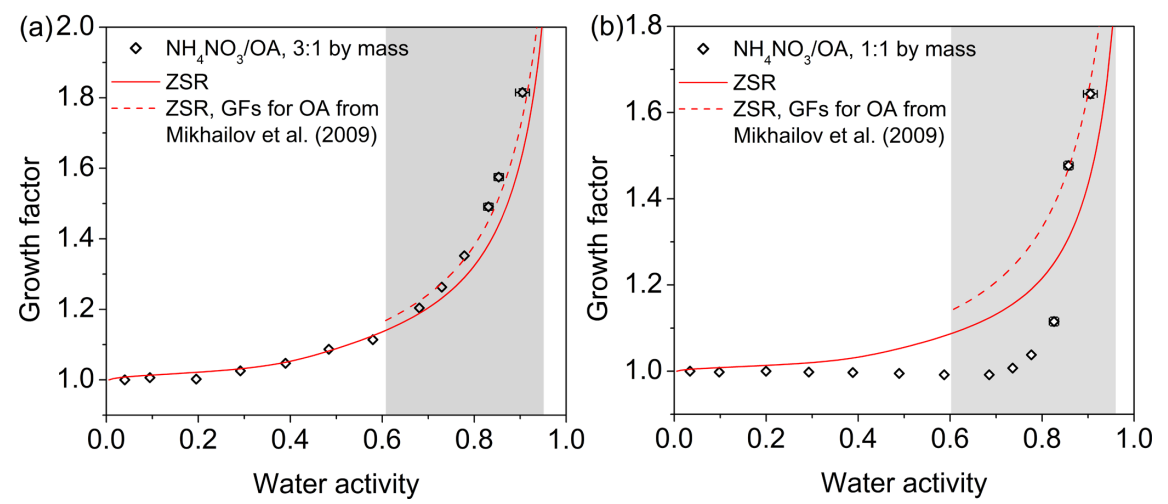

Figure 2. Hygroscopic growth factors of $100 \mathrm{~nm} \mathrm{NH}_{4} \mathrm{NO}_{3}$ / oxalic acid (OA) mixed particles with mass ratios of (a) $3: 1$ and (b) $1: 1$ as a function of water activity. The ZSR-predicted curves based on GF $=1$ for oxalic acid or GFs from Mikhailov et al. (2009) are indicated by red solid and dashed lines, respectively. The error bars representing the standard deviation of multiple measurements are generally not obvious compared to the size of the symbols. The shaded area shows potential water uptake by the oxalic acid component under high RH conditions.

$100 \mathrm{~nm}$ phthalic acid particles have a GF of 1.14 at $80 \% \mathrm{RH}$, close to the value of $\sim 1.12$ reported by Brooks et al. (2004).

\subsection{Water uptake behaviors of $\mathrm{NH}_{4} \mathrm{NO}_{3}$ / organic acid mixtures}

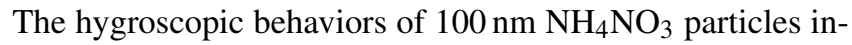
ternally mixed with organic acids at different mass ratios are shown in Figs. 2 and 3. As shown in Fig. 2, the hygroscopic growth of $\mathrm{NH}_{4} \mathrm{NO}_{3}$ / oxalic acid (OA) mixed particles shows various features with varying oxalic acid content. For the $3: 1 \mathrm{NH}_{4} \mathrm{NO}_{3} / \mathrm{OA}$ mixed system, the GFs of particles increase gradually with elevated $\mathrm{RH}$, and no prompt deliquescence behavior is observed in the RH range studied. The ZSR rule could describe the hygroscopic growth of mixed particles well when taking into account the dissolution of oxalic acid at RH higher than $70 \%$, as indicated by the good agreement between measurements and estimates based on GFs of oxalic acid from Mikhailov et al. (2009). The $1: 1 \mathrm{NH}_{4} \mathrm{NO}_{3} / \mathrm{OA}$ mixed particles take up no water below $80 \% \mathrm{RH}$ and exhibit a distinct deliquescence transition at about $86 \% \mathrm{RH}$. It can be seen that the ZSR predictions based on our measurements fail to reproduce the hygroscopic growth of $\mathrm{NH}_{4} \mathrm{NO}_{3} / \mathrm{OA}$ mixed particles with an equal mass ratio in the whole $\mathrm{RH}$ range. After full deliquescence, the water contents associated with the $1: 1 \mathrm{NH}_{4} \mathrm{NO}_{3} / \mathrm{OA}$ mixed particles are comparable to the ZSR predictions based on GFs of oxalic acid from Mikhailov et al. (2009), indicating that water uptake of mixed particles is enhanced by dissolution of solid oxalic acid at high RH. It is obvious that the ammonium nitrate in the initial mixed particles exists in a crystalline form rather than an amorphous one as in the pure component particles. The possible reason is that the solid oxalic acid dihydrate seeds formed in the mixed droplets during the drying process could trigger the heterogeneous nucleation of ammonium nitrate. The previous study has reported that the presence of solid succinic acid seeds dramatically lowered the barrier to promote the crystallization of ammonium nitrate even when succinic acid content was only $25 \%$ by mass (Lightstone et al., 2000). In contrast to ammonium nitrate/succinic acid mixtures, the deliquescence transition of ammonium nitrate is not observed for the $3: 1 \mathrm{NH}_{4} \mathrm{NO}_{3} / \mathrm{OA}$ mixed particles, suggesting that the minor OA fraction could not effectively initiate the crystallization of ammonium nitrate. The hygroscopic behavior of $\mathrm{NH}_{4} \mathrm{NO}_{3} / \mathrm{OA}$ mixed particles also reveals the crystallization of oxalic acid with the presence of hygroscopic $\mathrm{NH}_{4} \mathrm{NO}_{3}$ at low $\mathrm{RH}$. However, our previous study indicates that the coexisting hygroscopic organics such as levoglucosan and malonic acid could hinder the crystallization of oxalic acid upon dehydration (Jing et al., 2016). It can be concluded that the interactions between $\mathrm{NH}_{4} \mathrm{NO}_{3}$ and oxalic acid have greater influence on the phase state of $\mathrm{NH}_{4} \mathrm{NO}_{3}$ than oxalic acid. Compared to the hygroscopic growth of $\mathrm{NH}_{4} \mathrm{NO}_{3} / \mathrm{OA}$ mixed particles, oxalic acid has a slight influence on the deliquescence transition of ammonium sulfate, as indicated by the slightly decreased deliquescence point of mixed particles relative to pure ammonium sulfate (Jing et al., 2016; Wang et al., 2017).

Figure 3 illustrates hygroscopic characteristics of $\mathrm{NH}_{4} \mathrm{NO}_{3}$ particles internally mixed at equal mass ratios with malonic acid (MA), succinic acid (SA) and phthalic acid (PA), respectively. The measured hygroscopic growth of $\mathrm{NH}_{4} \mathrm{NO}_{3}$ / MA mixed particles is in fair agreement with ZSR predictions. This suggests that the presence of malonic acid has no effect on the hygroscopic behavior of ammonium nitrate. However, the malonic acid could dramatically influence the deliquescence behavior of ammonium sulfate by promoting water uptake of mixed particles under low RH conditions (Prenni et al., 2003). For $\mathrm{NH}_{4} \mathrm{NO}_{3} / \mathrm{SA}$ mixed particles, no water uptake is observed until RH increases to $60 \%$, consistent with the reported deliquescence point of $60.6 \pm 0.4 \%$ for equal mass $\mathrm{NH}_{4} \mathrm{NO}_{3} / \mathrm{SA}$ mixed particles 


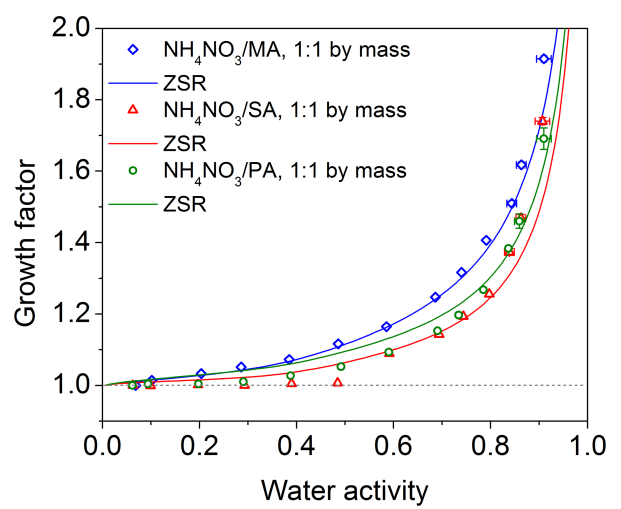

Figure 3. Hygroscopic growth factors of $100 \mathrm{~nm}$ internally mixed particles composed of $\mathrm{NH}_{4} \mathrm{NO}_{3} /$ malonic acid (MA), $\mathrm{NH}_{4} \mathrm{NO}_{3} /$ succinic acid (SA) and $\mathrm{NH}_{4} \mathrm{NO}_{3} /$ phthalic acid (PA) with equal mass ratios as a function of water activity. The blue, red and green solid lines indicate the hygroscopic growth predicted from the ZSR method. The error bars representing the standard deviation of multiple measurements are generally not obvious compared to the size of the symbols.

using electrodynamic balance technology (Lightstone et al., 2000). It is obvious that succinic acid could influence the phase behavior of ammonium nitrate. The crystallization of ammonium nitrate initiated by heterogeneous nucleation is favored by the presence of solid succinic acid seeds. The ZSR predictions underestimated the water uptake of $\mathrm{NH}_{4} \mathrm{NO}_{3} / \mathrm{SA}$ mixed particles above $80 \% \mathrm{RH}$. This phenomenon can be attributed to the partial dissolution of succinic acid, which thus contributed to water uptake by mixed aerosols at high RH. The early studies also found the enhanced hygroscopic growth of multicomponent aerosols containing succinic acid compared to ZSR estimates without taking limited solubility of succinic acid into account (Svenningsson et al., 2006; Y. Wang et al., 2016). For $\mathrm{NH}_{4} \mathrm{NO}_{3} / \mathrm{OA}$ and $\mathrm{NH}_{4} \mathrm{NO}_{3} / \mathrm{SA}$ mixed particles, the water uptake by the $\mathrm{NH}_{4} \mathrm{NO}_{3}$ component at high $\mathrm{RH}$ could trigger the partial or complete dissolution of oxalic acid and succinic acid. This behavior could be expected for a system at thermodynamic equilibrium, corresponding to a particle with an aqueous phase of the inorganic and organic composition, and solid organic acid (Clegg and Seinfeld, 2006). When the solid organic acids are in a metastable state, the complete dissolution could occur for aerosol particles composed of inorganic salt and organic acid above the deliquescence point of inorganic salt (Choi and Chan, 2002; Clegg and Seinfeld, 2006). Compared to ammonium nitrate, the deliquescence behavior and water uptake of ammonium sulfate are almost not affected by succinic acid (Prenni et al., 2003). The $\mathrm{NH}_{4} \mathrm{NO}_{3} / \mathrm{PA}$ mixed particles show continuous water uptake without obvious phase transitions over the whole RH range. At high RH, the ZSR rule could reproduce the GFs of mixed particles while significant deviation between measurements and predictions is observed at low and medium RH. The possible reason is that due to mass transfer limitation the residence time of $5 \mathrm{~s}$ appears to be

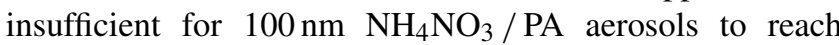
hygroscopic equilibrium in the low and medium $\mathrm{RH}$ range.

\subsection{Water uptake behaviors of $\mathrm{NaNO}_{3}$ / organic acid mixtures}

Figure 4 shows the hygroscopic growth of $100 \mathrm{~nm} \mathrm{NaNO}_{3}$ particles internally mixed at equal mass ratios with oxalic acid, malonic acid, succinic acid and phthalic acid, respectively. As can be seen in Fig. 4a, 1:1 $\mathrm{NaNO}_{3} / \mathrm{OA}$ mixed particles exhibit gradual water uptake without prompt deliquescence transition. The comparisons of measurement results and ZSR predictions suggest that sodium nitrate still remains amorphous and thus contributes to water uptake of mixed particles from low $\mathrm{RH}$, which eventually results in the dissolution of oxalic acid at high RH. In contrast to ammonium nitrate, the crystallization of sodium nitrate does not occur, even with the presence of oxalic acid at half mass fraction. For 1:1 $\mathrm{NaNO}_{3} / \mathrm{MA}$ mixed particles, the continuous hygroscopic growth of this mixed system agrees well with the ZSR predicted curve across all RH values studied. The prior study has indicated that the reaction between malonic acid and sodium nitrate within aerosols during the dehydration process could lead to considerable nitrate depletion and formation of organic salts due to the evaporation of $\mathrm{HNO}_{3}$ (Wang and Laskin, 2014). However, it is clear that this reaction has negligible impacts on the overall hygroscopic behavior of $\mathrm{NaNO}_{3} / \mathrm{MA}$ aerosols, as indicated by the good agreement between measured growth and ZSR predictions in the RH range studied. It can be explained by the fact that the hygroscopic growth of sodium malonate is comparable to that of malonic acid at each given RH (Wu et al., 2011). Disodium malonate has a GF of 1.78 at $90 \% \mathrm{RH}$ (Wu et al., 2011). The field measurement has observed the formation of sodium malonate in ambient aerosols (Laskin et al., 2012).

In the case of $1: 1 \mathrm{NaNO}_{3} / \mathrm{SA}$ mixed particles (Fig. 4c), no distinct deliquescence transition was observed upon hydration, which differed from the water uptake behavior of $1: 1 \mathrm{NH}_{4} \mathrm{NO}_{3} / \mathrm{SA}$. Again, it shows sodium nitrate is difficult to crystallize despite the presence of succinic acid that has a high deliquescence point. In addition, the amount of water uptake by mixed particles is significantly larger than predictions from the ZSR rule above $60 \% \mathrm{RH}$. The dissolution of succinic acid in aqueous $\mathrm{NaNO}_{3}$ solution should be responsible for enhanced water uptake of mixed particles. As shown in Fig. 4d, the equal mass $\mathrm{NaNO}_{3} / \mathrm{PA}$ mixed aerosols also present continuous water uptake from low $\mathrm{RH}$. In contrast to the $1: 1 \mathrm{NaNO}_{3} / \mathrm{SA}$ mixed system, the dramatic decrease in the amount of water uptake by the $1: 1$ $\mathrm{NaNO}_{3} /$ PA mixed system can be observed over the whole $\mathrm{RH}$ range compared to ZSR estimates. This discrepancy appears to be caused by mass transfer limitation. It has been 

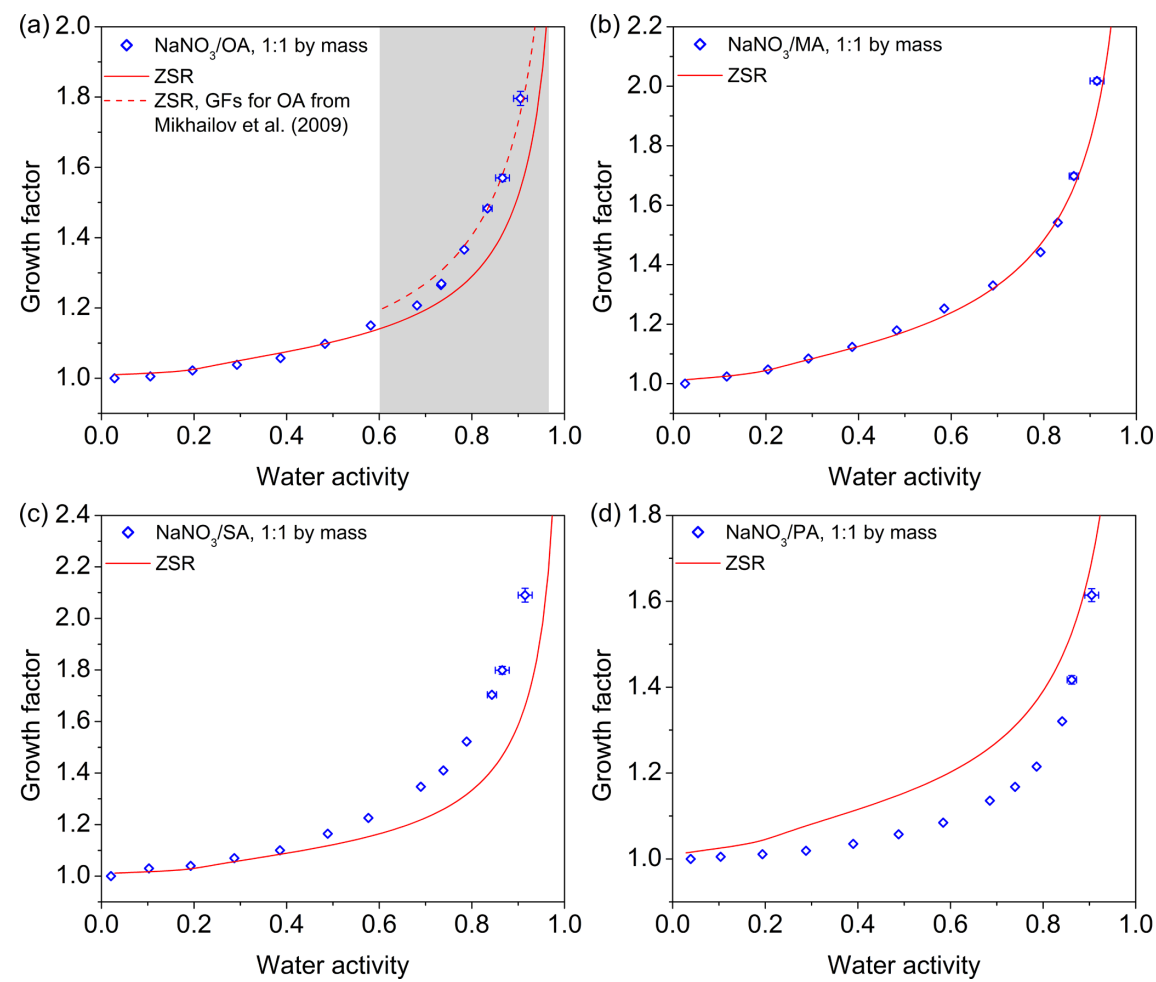

Figure 4. Hygroscopic growth factors of $100 \mathrm{~nm}$ internally mixed particles composed of $\mathrm{NaNO}_{3} /$ oxalic acid $(\mathrm{OA})(\mathbf{a}), \mathrm{NaNO} / \mathrm{malonic}$ acid (MA) (b), $\mathrm{NaNO}_{3} /$ succinic acid (SA) (c) and $\mathrm{NaNO}_{3} /$ phthalic acid (PA) (d) with equal mass ratios as a function of water activity. The red line indicates the hygroscopic growth predicted from the ZSR method. For the $\mathrm{NaNO}_{3}$ / oxalic acid (OA) mixture, the ZSR-predicted curve based on the GFs for OA from Mikhailov et al. (2009) is presented by the dashed line. The shaded area shows potential water uptake by the oxalic acid component. The error bars representing the standard deviation of multiple measurements are not obvious compared to the size of the symbols.

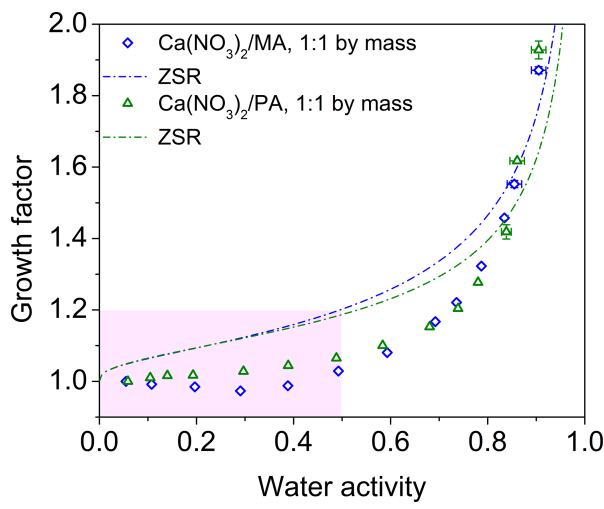

Figure 5. Hygroscopic growth factors of $100 \mathrm{~nm}$ internally mixed particles composed of $\mathrm{Ca}\left(\mathrm{NO}_{3}\right)_{2}$ with malonic acid (MA) or phthalic acid (PA) at equal mass ratios as a function of water activity. The blue and green dashed dotted lines indicate the hygroscopic growth predicted from the ZSR method. The error bars representing the standard deviation of multiple measurements are not obvious compared to the size of the symbols. The shaded area shows no significant water uptake by the mixed systems under low RH conditions. found that after the drying process, aerosol particles containing an inorganic salt and an organic acid with limited solubility tend to remain separated in phase, with the organic phase distributed at the outer layer (Peckhaus et al., 2012; Veghte et al., 2014). Zhou et al. (2014) observed the phase separation behavior of ammonium sulfate / phthalic acid mixed particles due to the salting-out effect. It should be noted that phthalic acid has a much lower solubility $(0.41 \mathrm{~g} / 100 \mathrm{~mL})$ and oxygen: carbon ratio $(\mathrm{O}: \mathrm{C}=0.5)$ than other organic acids such as oxalic acid $(9.5 \mathrm{~g} / 100 \mathrm{~mL}, \mathrm{O}: \mathrm{C}=2)$, malonic acid $(76 \mathrm{~g} / 100 \mathrm{~mL}, \mathrm{O}: \mathrm{C}=1.33)$ and succinic acid $(8.35 \mathrm{~g} / 100 \mathrm{~mL}, \mathrm{O}: \mathrm{C}=1)$. It has been found that a particle containing one dicarboxylic acid with limited solubility $(<1 \mathrm{~g} / 100 \mathrm{~mL})$ and ammonium sulfate would form phaseseparated structures upon drying (Veghte et al., 2014). The prior studies observed that liquid-liquid phase separation never occurred for mixed systems containing organic species with the oxygen: carbon elemental ratio $(\mathrm{O}: \mathrm{C})$ larger than 0.8 , and it always occurred for $\mathrm{O}: \mathrm{C}$ less than 0.5 (You et al., 2013). Considering the low solubility and oxygen : carbon ratio of phthalic acid, the occurrence of phase-separated structures for phthalic-acid-containing particles can be expected. As shown in Fig. S2, a cover layer can be observed at the 

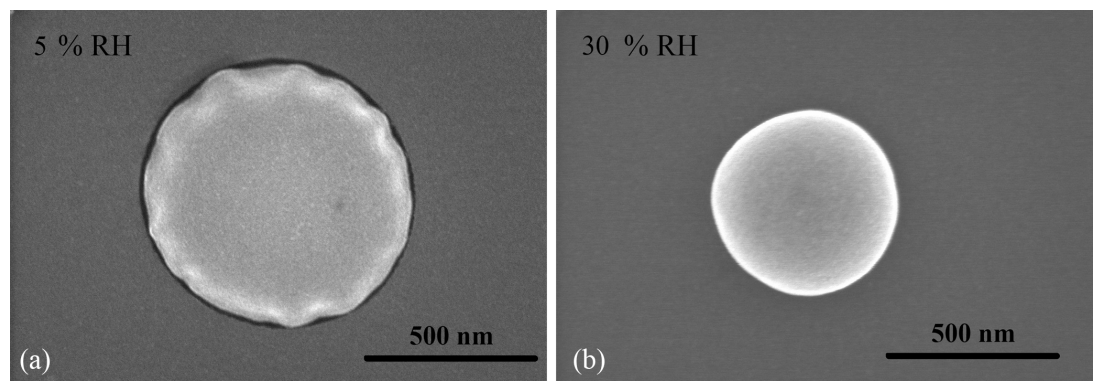

Figure 6. SEM micrographs of deposited particles composed of calcium nitrate and malonic acid before conditioning (a) and after conditioning at $30 \% \mathrm{RH}(\mathbf{b})$.

border of the dry $\mathrm{NaNO}_{3} /$ phthalic acid mixed particle. The prior study for ammonium sulfate / succinic acid mixtures showed that mixed particles with a core-shell structure had reduced hygroscopic growth relative to the well-mixed particles (Maskey et al., 2014). Similarly, the phthalic acid layer likely inhibits the water transfer from gas phase to $\mathrm{NaNO}_{3}$ phase, thus resulting in the lower growth of particles.

\subsection{Water uptake behaviors of $\mathrm{Ca}\left(\mathrm{NO}_{3}\right)_{2}$ / organic acid mixtures}

Due to the interference of precipitation, only the hygroscopic growth of $100 \mathrm{~nm} \mathrm{Ca}\left(\mathrm{NO}_{3}\right)_{2}$ particles internally mixed with malonic acid or phthalic acid at equal mass ratios is given in Fig. 5. The particle size for $1: 1 \mathrm{Ca}\left(\mathrm{NO}_{3}\right)_{2} / \mathrm{MA}$ aerosols upon hydration shows a slight decrease between 10 and $40 \% \mathrm{RH}$ and subsequently continuous growth without obvious phase transition in the whole $\mathrm{RH}$ range, which distinguishes from the hygroscopic growth of pure $\mathrm{Ca}\left(\mathrm{NO}_{3}\right)_{2}$ and malonic acid. A similar hygroscopic behavior including the decrease in particle size at low RH was also observed for mixed $\mathrm{NH}_{4} \mathrm{NO}_{3}$ / protein particles (Mikhailov et al., 2004) as well as amorphous oxalic acid and SOA particles derived from methylglyoxal-methylamine aqueous reactions upon hydration below $50 \% \mathrm{RH}$ (Mikhailov et al., 2009; Hawkins et al., 2014). As shown in Fig. 6, the $\mathrm{Ca}\left(\mathrm{NO}_{3}\right)_{2} /$ malonic acid $(1: 1)$ particle has a more compact sphere structure at $30 \% \mathrm{RH}$ relative to the gel-like structure under dry conditions. This specific behavior of particle shrinkage upon hydration typically results from the humidity-induced transformation of porous, gel-like structures into more compact spheres for (semi-)solid amorphous particles (Mikhailov et al., 2009). Thus, the hygroscopic characteristics of $\mathrm{Ca}\left(\mathrm{NO}_{3}\right)_{2}$ / MA aerosols suggest the structure of mixed particles can be distinguished from that of pure component particles.

The $1: 1 \mathrm{Ca}\left(\mathrm{NO}_{3}\right)_{2} / \mathrm{PA}$ aerosols take up water gradually with exposure of elevated $\mathrm{RH}$. The overestimated water uptake by the ZSR rule could be observed below $80 \% \mathrm{RH}$. This substantial deviation between predictions and measurements can be attributed to mass transfer limitation in the aerosols (Chan and Chan, 2005). For the $\mathrm{Ca}\left(\mathrm{NO}_{3}\right)_{2} /$ phthalic acid mixed particles, the clear organic cover layer at the border can be observed upon hydration, seen in Fig. S2 When the residence time of $5 \mathrm{~s}$ in the HTDMA measurements was expanded to $27 \mathrm{~s}$, a slight increase (0.02-0.04) in GFs was observed for phthalic-acid-containing mixed particles at $80 \% \mathrm{RH}$. The outer organic layer may result in the mass transfer limitation of water. Due to low molecular diffusivity, organic (semi-)solid amorphous structures at low RH could retard the equilibrium between evaporation and condensation of water from submicron particles on (multi-)second timescales (Booth et al., 2014; Price et al., 2014), thus kinetically inhibiting the hygroscopic growth of particles with insufficient equilibrium time (Mikhailov et al., 2009). When ambient humidity increases to high RH such as $80 \%$, more water content in particles significantly reduces the impacts of mass transfer limitation, as indicated by the general agreement between predictions and measurements above $80 \%$ RH in Fig. 5. Although it has been found that nitrate depletions likely occur within $\mathrm{Ca}\left(\mathrm{NO}_{3}\right)_{2}$ / organic acid aerosols, the reactions between $\mathrm{Ca}\left(\mathrm{NO}_{3}\right)_{2}$ and organic acids may have no obvious impacts on the hygroscopic growth in our experiment due to mass transfer limitation. Considering $\mathrm{Ca}\left(\mathrm{NO}_{3}\right)_{2} /$ organic acid particles in the viscous semisolid state after dehydration (Wang and Laskin, 2014), the low molecular diffusivity in amorphous phases could limit the release of $\mathrm{HNO}_{3}$ from particle phase on (multi-)second timescales. In addition, our previous study also showed that due to the presence of coexisting hygroscopic species, the transformation of solid state into a viscous semisolid state for $\mathrm{NaCl}$ / oxalic acid mixed particles considerably inhibited chloride depletions or $\mathrm{HCl}$ evaporation during the dehydration process (Peng et al., 2016).

\section{Conclusions and atmospheric implications}

Our results reveal that the nitrate salt / organic acid mixed aerosols exhibit varying phase behavior and hygroscopic growth depending upon the type of components present in the particles. Whereas pure nitrate salt particles show con- 
tinuous water uptake with increasing $\mathrm{RH}$, the deliquescence transition is still observed for ammonium nitrate particles internally mixed with organic acids such as oxalic acid and succinic acid with a high deliquescence point. In contrast to ammonium nitrate, the hygroscopic nature of submicron sodium nitrate aerosols is characterized by continuous growth, even with the presence of oxalic acid or succinic acid, indicating that sodium nitrate particles tend to exist in a liquid-like state under near-dry conditions. Although pure oxalic and succinic acids exhibit no hygroscopic growth in the $\mathrm{RH}$ range studied (0-90\%), the nitrate salt particles mixed with oxalic or succinic acid have enhanced hygroscopic growth at high RH due to water uptake by dissolved fractions of oxalic or succinic acid. In the case of calcium nitrate particles containing malonic acid or phthalic acid, the water uptake of mixed aerosols is significantly inhibited in the low and moderate $\mathrm{RH}$ range, likely due to mass transfer limitation in amorphous solids with high viscosity. Our findings indicate that the coexisting organic acids modify the phase and morphology of nitrate salt particles in the low and medium RH range, which thus likely result in obvious enhancement or suppression of water uptake with further increasing RH.

Due to the enhanced fractions of nitrate in particulate matter and sulfate controlled by policies (Hodas et al., 2014), the nitrate salt may play an important role in the hygroscopicity and thus the water content of aerosol particles in urban areas such as the eastern United States and eastern China, where nitrate concentrations are high (Zhang et al., 2015). The phase state and water uptake of atmospheric particles have crucial impacts on determining the role of aerosols in earth's climate and air quality. A good understanding of the phase state of atmospheric particles could reduce the uncertainty in radiative forcing estimates. The new findings for phase behavior of nitrate salts aid in further understanding the atmospheric lifetime, optical properties and cloud formation of nitrate salts. In addition, these experimental results can serve as a basis for the evaluation and improvement of thermodynamic models for the prediction of aerosols' physicochemical properties. The ongoing effort to understand the mechanisms of interactions between water and aerosol particles with varying compositions is of importance in incorporating these processes into global climate models.

Data availability. All data are available upon request from Bo Jing (jingbo109@163.com) or Maofa Ge (gemaofa@iccas.ac.cn).

The Supplement related to this article is available online at https://doi.org/10.5194/acp-18-5115-2018-supplement.
Author contributions. BJ and MG designed the experiments. BJ and $\mathrm{ZW}$ carried them out. BJ performed the data analysis and prepared the manuscript with contributions from all co-authors.

Competing interests. The authors declare that they have no conflict of interest.

Acknowledgements. This project was supported by the National Natural Science Foundation of China (contract no. 41227805, 91544227, 21477134) and the National Key Research and Development Program of China (2016YFC0202202). The authors would like to thank Chao Peng, Ying Zhang and Kaihui Xia for help in additional measurements during the revision period.

Edited by: Kimitaka Kawamura

Reviewed by: two anonymous referees

\section{References}

Badger, C. L., George, I., Griffiths, P. T., Braban, C. F., Cox, R. A., and Abbatt, J. P. D.: Phase transitions and hygroscopic growth of aerosol particles containing humic acid and mixtures of humic acid and ammonium sulphate, Atmos. Chem. Phys., 6, 755-768, https://doi.org/10.5194/acp-6-755-2006, 2006.

Booth, A. M., Murphy, B., Riipinen, I., Percival, C. J., and Topping, D. O.: Connecting bulk viscosity measurements to kinetic limitations on attaining equilibrium for a model aerosol composition, Environ. Sci. Technol., 48, 9298-9305, https://doi.org/10.1021/es501705c, 2014.

Boreddy, S. K. R., Kawamura, K., and Jung, J.: Hygroscopic properties of particles nebulized from water extracts of aerosols collected at Chichijima Island in the western North Pacific: An outflow region of Asian dust, J. Geophys. Res.-Atmos., 119, 167178, https://doi.org/10.1002/2013jd020626, 2014a.

Boreddy, S. K. R. and Kawamura, K.: Hygroscopic growth of water-soluble matter extracted from remote marine aerosols over the western North Pacific: Influence of pollutants transported from East Asia, Sci. Total. Environ., 557, 285-295, https://doi.org/10.1016/j.scitotenv.2016.03.096, 2016.

Boreddy, S. K. R., Kawamura, K., Mkoma, S., and Fu, P.: Hygroscopic behavior of water-soluble matter extracted from biomass burning aerosols collected at a rural site in Tanzania, East Africa, J. Geophys. Res.-Atmos., 119, 12233-12245, https://doi.org/10.1002/2014jd021546, 2014b.

Boreddy, S. K. R., Kawamura, K., and Haque, M. M.: Long-term (2001-2012) observation of the modeled hygroscopic growth factor of remote marine TSP aerosols over the western North Pacific: impact of long-range transport of pollutants and their mixing states, Phys. Chem. Chem. Phys., 17, 29344-29353, https://doi.org/10.1039/c5cp05315c, 2015.

Brooks, S. D., DeMott, P. J., and Kreidenweis, S. M.: Water uptake by particles containing humic materials and mixtures of humic materials with ammonium sulfate, Atmos. Environ., 38, 18591868, https://doi.org/10.1016/j.atmosenv.2004.01.009, 2004.

Carrico, C. M., Petters, M. D., Kreidenweis, S. M., Collett Jr., J. L., Engling, G., and Malm, W. C.: Aerosol hygroscopicity 
and cloud droplet activation of extracts of filters from biomass burning experiments, J. Geophys. Res.-Atmos., 113, D08206, https://doi.org/10.1029/2007jd009274, 2008.

Carslaw, K. S., Lee, L. A., Reddington, C. L., Pringle, K. J., Rap, A., Forster, P. M., Mann, G. W., Spracklen, D. V., Woodhouse, M. T., Regayre, L. A., and Pierce, J. R.: Large contribution of natural aerosols to uncertainty in indirect forcing, Nature, 503, 67-71, https://doi.org/10.1038/nature12674, 2013.

Chan, M. N. and Chan, C. K.: Mass transfer effects in hygroscopic measurements of aerosol particles, Atmos. Chem. Phys., 5, 2703-2712, https://doi.org/10.5194/acp-5-2703-2005, 2005.

Cheng, Y., Zheng, G., Wei, C., Mu, Q., Zheng, B., Wang, Z., Gao, M., Zhang, Q., He, K., Carmichael, G., Poschl, U., and Su, H.: Reactive nitrogen chemistry in aerosol water as a source of sulfate during haze events in China, Sci. Adv., 2, e1601530, https://doi.org/10.1126/sciadv.1601530, 2016.

Choi, M. Y. and Chan, C. K.: The effects of organic species on the hygroscopic behaviors of inorganic aerosols, Environ. Sci. Technol., 36, 2422-2428, https://doi.org/10.1021/es0113293, 2002.

Clegg, S. L. and Seinfeld, J. H.: Thermodynamic models of aqueous solutions containing inorganic electrolytes and dicarboxylic acids at $298.15 \mathrm{~K}$. 1. The acids as nondissociating components, J. Phys. Chem. A, 110, 5692-5717, https://doi.org/10.1021/jp056149k, 2006.

Cruz, C. N. and Pandis, S. N.: Deliquescence and hygroscopic growth of mixed inorganic-organic atmospheric aerosol, Environ. Sci. Technol., 34, 4313-4319, https://doi.org/10.1021/es9907109, 2000.

Davis, R. D., Lance, S., Gordon, J. A., Ushijima, S. B., and Tolbert, M. A.: Contact efflorescence as a pathway for crystallization of atmospherically relevant particles, P. Natl. Acad. Sci. USA, 112, 15815-15820, https://doi.org/10.1073/pnas.1522860113, 2015.

Decesari, S., Facchini, M. C., Fuzzi, S., McFiggans, G. B., Coe, H., and Bower, K. N.: The water-soluble organic component of size-segregated aerosol, cloud water and wet depositions from Jeju Island during ACE-Asia, Atmos. Environ., 39, 211-222, https://doi.org/10.1016/j.atmosenv.2004.09.049, 2005.

Decesari, S., Fuzzi, S., Facchini, M. C., Mircea, M., Emblico, L., Cavalli, F., Maenhaut, W., Chi, X., Schkolnik, G., Falkovich, A., Rudich, Y., Claeys, M., Pashynska, V., Vas, G., Kourtchev, I., Vermeylen, R., Hoffer, A., Andreae, M. O., Tagliavini, E., Moretti, F., and Artaxo, P.: Characterization of the organic composition of aerosols from Rondônia, Brazil, during the LBA-SMOCC 2002 experiment and its representation through model compounds, Atmos. Chem. Phys., 6, 375-402, https://doi.org/10.5194/acp-6-375-2006, 2006.

Faust, J. A., Wong, J. P., Lee, A. K., and Abbatt, J. P.: Role of aerosol liquid water in secondary organic aerosol formation from volatile organic compounds, Environ. Sci. Technol., 51, 14051413, https://doi.org/10.1021/acs.est.6b04700, 2017.

Gibson, E. R., Hudson, P. K., and Grassian, V. H.: Physicochemical properties of nitrate aerosols: Implications for the atmosphere, J. Phys. Chem. A, 110, 11785-11799, https://doi.org/10.1021/jp063821k, 2006.

Gysel, M., Weingartner, E., and Baltensperger, U.: Hygroscopicity of aerosol particles at low temperatures. 2. Theoretical and experimental hygroscopic properties of laboratory generated aerosols, Environ. Sci. Technol., 36, 63-68, https://doi.org/10.1021/es010055g, 2002.
Gysel, M., Weingartner, E., Nyeki, S., Paulsen, D., Baltensperger, U., Galambos, I., and Kiss, G.: Hygroscopic properties of water-soluble matter and humic-like organics in atmospheric fine aerosol, Atmos. Chem. Phys., 4, 35-50, https://doi.org/10.5194/acp-4-35-2004, 2004.

Hamer, W. J. and Wu, Y. C.: Osmotic Coefficients and Mean Activity Coefficients of Uni-univalent Electrolytes in Water at $25^{\circ} \mathrm{C}$, J. Phys. Chem. Ref. Data, 1, 1047-1100, https://doi.org/10.1063/1.3253108, 1972.

Hartz, K. E. H., Tischuk, J. E., Chan, M. N., Chan, C. K., Donahue, N. M., and Pandis, S. N.: Cloud condensation nuclei activation of limited solubility organic aerosol, Atmos. Environ., 40, 605-617, https://doi.org/10.1016/j.atmosenv.2005.09.076, 2006.

Hawkins, L. N., Baril, M. J., Sedehi, N., Galloway, M. M., De Haan, D. O., Schill, G. P., and Tolbert, M. A.: Formation of semisolid, oligomerized aqueous SOA: lab simulations of cloud processing, Environ. Sci. Technol., 48, 2273-2280, https://doi.org/10.1021/es4049626, 2014.

Haywood, J. and Boucher, O.: Estimates of the direct and indirect radiative forcing due to tropospheric aerosols: A review, Rev. Geophys., 38, 513-543, https://doi.org/10.1029/1999rg000078, 2000.

Hodas, N., Sullivan, A. P., Skog, K., Keutsch, F. N., Collett, J. L., Decesari, S., Facchini, M. C., Carlton, A. G., Laaksonen, A., and Turpin, B. J.: Aerosol liquid water driven by anthropogenic nitrate: implications for lifetimes of watersoluble organic gases and potential for secondary organic aerosol formation, Environ. Sci. Technol., 48, 11127-11136, https://doi.org/10.1021/es5025096, 2014.

Hodas, N., Zuend, A., Mui, W., Flagan, R. C., and Seinfeld, J. H.: Influence of particle-phase state on the hygroscopic behavior of mixed organic-inorganic aerosols, Atmos. Chem. Phys., 15, 5027-5045, https://doi.org/10.5194/acp-15-5027-2015, 2015.

Hoffman, R. C., Laskin, A., and Finlayson-Pitts, B. J.: Sodium nitrate particles: physical and chemical properties during hydration and dehydration, and implications for aged sea salt aerosols, J. Aerosol Sci., 35, 869-887, https://doi.org/10.1016/j.jaerosci.2004.02.003, 2004.

Hu, D., Chen, J., Ye, X., Li, L., and Yang, X.: Hygroscopicity and evaporation of ammonium chloride and ammonium nitrate: Relative humidity and size effects on the growth factor, Atmos. Environ., 45, 2349-2355, https://doi.org/10.1016/j.atmosenv.2011.02.024, 2011.

Huang, R. J., Zhang, Y., Bozzetti, C., Ho, K. F., Cao, J. J., Han, Y., Daellenbach, K. R., Slowik, J. G., Platt, S. M., Canonaco, F., Zotter, P., Wolf, R., Pieber, S. M., Bruns, E. A., Crippa, M., Ciarelli, G., Piazzalunga, A., Schwikowski, M., Abbaszade, G., SchnelleKreis, J., Zimmermann, R., An, Z., Szidat, S., Baltensperger, U., El Haddad, I., and Prevot, A. S.: High secondary aerosol contribution to particulate pollution during haze events in China, Nature, 514, 218-222, https://doi.org/10.1038/nature13774, 2014.

Jing, B., Tong, S., Liu, Q., Li, K., Wang, W., Zhang, Y., and Ge, M.: Hygroscopic behavior of multicomponent organic aerosols and their internal mixtures with ammonium sulfate, Atmos. Chem. Phys., 16, 4101-4118, https://doi.org/10.5194/acp-164101-2016, 2016.

Jing, B., Peng, C., Wang, Y., Liu, Q., Tong, S., Zhang, Y., and Ge, M.: Hygroscopic properties of potassium chloride and its internal mixtures with organic compounds relevant 
to biomass burning aerosol particles, Sci. Rep., 7, 43572, https://doi.org/10.1038/srep43572, 2017.

Kanakidou, M., Seinfeld, J. H., Pandis, S. N., Barnes, I., Dentener, F. J., Facchini, M. C., Van Dingenen, R., Ervens, B., Nenes, A., Nielsen, C. J., Swietlicki, E., Putaud, J. P., Balkanski, Y., Fuzzi, S., Horth, J., Moortgat, G. K., Winterhalter, R., Myhre, C. E. L., Tsigaridis, K., Vignati, E., Stephanou, E. G., and Wilson, J.: Organic aerosol and global climate modelling: a review, Atmos. Chem. Phys., 5, 1053-1123, https://doi.org/10.5194/acp-5-10532005, 2005.

Kawamura, K. and Bikkina, S.: A review of dicarboxylic acids and related compounds in atmospheric aerosols: Molecular distributions, sources and transformation, Atmos. Res., 170, 140-160, https://doi.org/10.1016/j.atmosres.2015.11.018, 2016.

Kawamura, K. and Ikushima, K.: Seasonal-changes in the distribution of dicarboxylic-acids in the urban atmosphere, Environ. Sci. Technol., 27, 2227-2235, https://doi.org/10.1021/es00047a033, 1993.

Kawamura, K., Kasukabe, H., and Barrie, L. A.: Source and reaction pathways of dicarboxylic acids, ketoacids and dicarbonyls in arctic aerosols: One year of observations, Atmos. Environ., 30, 1709-1722, https://doi.org/10.1016/1352-2310(95)00395-9, 1996.

Krieger, U. K., Marcolli, C., and Reid, J. P.: Exploring the complexity of aerosol particle properties and processes using single particle techniques, Chem. Soc. Rev., 41, 6631-6662, https://doi.org/10.1039/c2cs35082c, 2012.

Laskin, A., Moffet, R. C., Gilles, M. K., Fast, J. D., Zaveri, R. A., Wang, B. B., Nigge, P., and Shutthanandan, J.: Tropospheric chemistry of internally mixed sea salt and organic particles: Surprising reactivity of $\mathrm{NaCl}$ with weak organic acids, J. Geophys. Res.-Atmos., 117, D15302, https://doi.org/10.1029/2012jd017743, 2012.

Li, K., Li, J., Liggio, J., Wang, W., Ge, M., Liu, Q., Guo, Y., Tong, S., Li, J., Peng, C., Jing, B., Wang, D., and Fu, P.: Enhanced light scattering of secondary organic aerosols by multiphase reactions, Environ. Sci. Technol., 51, 1285-1292, https://doi.org/10.1021/acs.est.6b03229, 2017.

Lightstone, J. M., Onasch, T. B., Imre, D., and Oatis, S.: Deliquescence, efflorescence, and water activity in ammonium nitrate and mixed ammonium nitrate/succinic acid microparticles, J. Phys. Chem. A, 104, 9337-9346, https://doi.org/10.1021/jp002137h, 2000.

Liu, Q., Jing, B., Peng, C., Tong, S., Wang, W., and Ge, M.: Hygroscopicity of internally mixed multi-component aerosol particles of atmospheric relevance, Atmos. Environ., 125, 69-77, https://doi.org/10.1016/j.atmosenv.2015.11.003, 2016.

Malm, W. C. and Kreidenweis, S. M.: The effects of models of aerosol hygroscopicity on the apportionment of extinction, Atmos. Environ., 31, 1965-1976, https://doi.org/10.1016/s13522310(96)00355-x, 1997.

Martin, S. T.: Phase transitions of aqueous atmospheric particles, Chem. Rev., 100, 3403-3453, https://doi.org/10.1021/cr990034t, 2000.

Maskey, S., Chong, K. Y., Kim, G., Kim, J.-S., Ali, A., and Park, K.: Effect of mixing structure on the hygroscopic behavior of ultrafine ammonium sulfate particles mixed with succinic acid and levoglucosan, Particuology, 13, 27-34, https://doi.org/10.1016/j.partic.2013.08.004, 2014.
Mikhailov, E., Vlasenko, S., Niessner, R., and Pöschl, U.: Interaction of aerosol particles composed of protein and saltswith water vapor: hygroscopic growth and microstructural rearrangement, Atmos. Chem. Phys., 4, 323-350, https://doi.org/10.5194/acp-4323-2004, 2004.

Mikhailov, E., Vlasenko, S., Martin, S. T., Koop, T., and Pöschl, U.: Amorphous and crystalline aerosol particles interacting with water vapor: conceptual framework and experimental evidence for restructuring, phase transitions and kinetic limitations, Atmos. Chem. Phys., 9, 9491-9522, https://doi.org/10.5194/acp-9-94912009, 2009.

Peckhaus, A., Grass, S., Treuel, L., and Zellner, R.: Deliquescence and efflorescence behavior of ternary inorganic/organic/water aerosol particles, J. Phys. Chem. A, 116, 6199-6210, https://doi.org/10.1021/jp211522t, 2012.

Peng, C., Chan, M. N., and Chan, C. K.: The hygroscopic properties of dicarboxylic and multifunctional acids: Measurements and UNIFAC predictions, Environ. Sci. Technol., 35, 4495-4501, https://doi.org/10.1021/es0107531, 2001.

Peng, C., Jing, B., Guo, Y. C., Zhang, Y. H., and Ge, M. F.: Hygroscopic behavior of multicomponent aerosols involving $\mathrm{NaCl}$ and dicarboxylic acids, J. Phys. Chem. A, 120, 1029-1038, https://doi.org/10.1021/acs.jpca.5b09373, 2016.

Petters, M. D. and Kreidenweis, S. M.: A single parameter representation of hygroscopic growth and cloud condensation nucleus activity, Atmos. Chem. Phys., 7, 1961-1971, https://doi.org/10.5194/acp-7-1961-2007, 2007.

Prenni, A. J., DeMott, P. J., Kreidenweis, S. M., Sherman, D. E., Russell, L. M., and Ming, Y.: The effects of low molecular weight dicarboxylic acids on cloud formation, J. Phys. Chem. A, 105, 11240-11248, https://doi.org/10.1021/jp012427d, 2001.

Prenni, A. J., De Mott, P. J., and Kreidenweis, S. M.: Water uptake of internally mixed particles containing ammonium sulfate and dicarboxylic acids, Atmos. Environ., 37, 4243-4251, https://doi.org/10.1016/s1352-2310(03)00559-4, 2003.

Price, H. C., Murray, B. J., Mattsson, J., O’Sullivan, D., Wilson, T. W., Baustian, K. J., and Benning, L. G.: Quantifying water diffusion in high-viscosity and glassy aqueous solutions using a Raman isotope tracer method, Atmos. Chem. Phys., 14, 38173830, https://doi.org/10.5194/acp-14-3817-2014, 2014.

Robinson, R. A. and Stokes, R. H.: Electrolyte solutions, 2nd Edn., Dover Publications Inc., New York, USA, 2002.

Saxena, P. and Hildemann, L. M.: Water-soluble organics in atmospheric particles: A critical review of the literature and application of thermodynamics to identify candidate compounds, J. Atmos. Chem., 24, 57-109, https://doi.org/10.1007/bf00053823, 1996.

Shiraiwa, M., Li, Y., Tsimpidi, A. P., Karydis, V. A., Berkemeier, T., Pandis, S. N., Lelieveld, J., Koop, T., and Pöschl, U.: Global distribution of particle phase state in atmospheric secondary organic aerosols, Nat. Commun., 8, 15002, https://doi.org/10.1038/ncomms15002, 2017.

Sjogren, S., Gysel, M., Weingartner, E., Baltensperger, U., Cubison, M. J., Coe, H., Zardini, A. A., Marcolli, C., Krieger, U. K., and Peter, T.: Hygroscopic growth and water uptake kinetics of two-phase aerosol particles consisting of ammonium sulfate, adipic and humic acid mixtures, J. Aerosol Sci., 38, 157-171, https://doi.org/10.1016/j.jaerosci.2006.11.005, 2007. 
Stokes, R. H. and Robinson, R. A.: Interactions in aqueous nonelectrolyte solutions. I. Solute-solvent equilibria, J. Phys. Chem., 70, 2126-2131, https://doi.org/10.1021/j100879a010, 1966.

Stolzenburg, M. R. and McMurry, P. H.: Equations governing single and tandem DMA configurations and a new lognormal approximation to the transfer function, Aerosol Sci. Tech., 42, 421-432, https://doi.org/10.1080/02786820802157823, 2008.

Svenningsson, B., Rissler, J., Swietlicki, E., Mircea, M., Bilde, M., Facchini, M. C., Decesari, S., Fuzzi, S., Zhou, J., Mønster, J., and Rosenørn, T.: Hygroscopic growth and critical supersaturations for mixed aerosol particles of inorganic and organic compounds of atmospheric relevance, Atmos. Chem. Phys., 6, 1937-1952, https://doi.org/10.5194/acp-6-1937-2006, 2006.

Tan, F., Tong, S., Jing, B., Hou, S., Liu, Q., Li, K., Zhang, Y., and Ge, M.: Heterogeneous reactions of $\mathrm{NO}_{2}$ with $\mathrm{CaCO}_{3}$ $\left(\mathrm{NH}_{4}\right)_{2} \mathrm{SO}_{4}$ mixtures at different relative humidities, Atmos. Chem. Phys., 16, 8081-8093, https://doi.org/10.5194/acp-168081-2016, 2016.

Tang, I. N. and Munkelwitz, H. R.: Water activities, densities, and refractive-indexes of aqueous sulfates and sodium-nitrate droplets of atmospheric importance, J. Geophys. Res.-Atmos., 99, 18801-18808, https://doi.org/10.1029/94jd01345, 1994.

Veghte, D. P., Bittner, D. R., and Freedman, M. A.: Cryotransmission electron microscopy imaging of the morphology of submicrometer aerosol containing organic acids and ammonium sulfate, Anal. Chem., 86, 2436-2442, https://doi.org/10.1021/ac403279f, 2014.

Virtanen, A., Joutsensaari, J., Koop, T., Kannosto, J., Yli-Pirila, P., Leskinen, J., Makela, J. M., Holopainen, J. K., Pöschl, U., Kulmala, M., Worsnop, D. R., and Laaksonen, A.: An amorphous solid state of biogenic secondary organic aerosol particles, Nature, 467, 824-827, https://doi.org/10.1038/nature09455, 2010.

Wang, B. and Laskin, A.: Reactions between water-soluble organic acids and nitrates in atmospheric aerosols: Recycling of nitric acid and formation of organic salts, J. Geophys. Res.-Atmos., 119, 3335-3351, https://doi.org/10.1002/2013jd021169, 2014.

Wang, G., Zhang, R., Gomez, M. E., Yang, L., Zamora, M. L., Hu, M., Lin, Y., Peng, J., Guo, S., Meng, J., Li, J., Cheng, C., Hu, T., Ren, Y., Wang, Y., Gao, J., Cao, J., An, Z., Zhou, W., Li, G., Wang, J., Tian, P., Marrero-Ortiz, W., Secrest, J., Du, Z., Zheng, J., Shang, D., Zeng, L., Shao, M., Wang, W., Huang, Y., Wang, Y., Zhu, Y., Li, Y., Hu, J., Pan, B., Cai, L., Cheng, Y., Ji, Y., Zhang, F., Rosenfeld, D., Liss, P. S., Duce, R. A., Kolb, C. E., and Molina, M. J.: Persistent sulfate formation from London Fog to Chinese haze, P. Natl. Acad. Sci. USA, 113, 13630-13635, https://doi.org/10.1073/pnas.1616540113, 2016.
Wang, X., Jing, B., Tan, F., Ma, J., Zhang, Y., and Ge, M.: Hygroscopic behavior and chemical composition evolution of internally mixed aerosols composed of oxalic acid and ammonium sulfate, Atmos. Chem. Phys., 17, 12797-12812, https://doi.org/10.5194/acp-17-12797-2017, 2017.

Wang, Y., Jing, B., Guo, Y., Li, J., Tong, S., Zhang, Y., and Ge, M.: Water uptake of multicomponent organic mixtures and their influence on hygroscopicity of inorganic salts, J. Environ. Sci., 45, 156-163, https://doi.org/10.1016/j.jes.2016.01.013, 2016.

Wise, M. E., Surratt, J. D., Curtis, D. B., Shilling, J. E., and Tolbert, M. A.: Hygroscopic growth of ammonium sulfate/dicarboxylic acids, J. Geophys. Res.-Atmos., 108, 4638, https://doi.org/10.1029/2003jd003775, 2003.

Wu, Z. J., Nowak, A., Poulain, L., Herrmann, H., and Wiedensohler, A.: Hygroscopic behavior of atmospherically relevant water-soluble carboxylic salts and their influence on the water uptake of ammonium sulfate, Atmos. Chem. Phys., 11, 1261712626, https://doi.org/10.5194/acp-11-12617-2011, 2011.

You, Y., Renbaum-Wolff, L., and Bertram, A. K.: Liquid-liquid phase separation in particles containing organics mixed with ammonium sulfate, ammonium bisulfate, ammonium nitrate or sodium chloride, Atmos. Chem. Phys., 13, 11723-11734, https://doi.org/10.5194/acp-13-11723-2013, 2013.

Zhang, R., Wang, G., Guo, S., Zamora, M. L., Ying, Q., Lin, Y., Wang, W., Hu, M., and Wang, Y.: Formation of urban fine particulate matter, Chem. Rev., 115, 3803-3855, https://doi.org/10.1021/acs.chemrev.5b00067, 2015.

Zhou, Q., Pang, S. F., Wang, Y., Ma, J. B., and Zhang, Y. H.: Confocal Raman studies of the evolution of the physical state of mixed phthalic acid/ammonium sulfate aerosol droplets and the effect of substrates, J. Phys. Chem. B, 118, 6198-6205, https://doi.org/10.1021/jp5004598, 2014.

Zuend, A., Marcolli, C., Luo, B. P., and Peter, T.: A thermodynamic model of mixed organic-inorganic aerosols to predict activity coefficients, Atmos. Chem. Phys., 8, 4559-4593, https://doi.org/10.5194/acp-8-4559-2008, 2008.

Zuend, A., Marcolli, C., Booth, A. M., Lienhard, D. M., Soonsin, V., Krieger, U. K., Topping, D. O., McFiggans, G., Peter, T., and Seinfeld, J. H.: New and extended parameterization of the thermodynamic model AIOMFAC: calculation of activity coefficients for organic-inorganic mixtures containing carboxyl, hydroxyl, carbonyl, ether, ester, alkenyl, alkyl, and aromatic functional groups, Atmos. Chem. Phys., 11, 9155-9206, https://doi.org/10.5194/acp-11-9155-2011, 2011. 